\title{
An Overview of Bioaerosols Suspended in the Atmosphere of Metropolitan Zone of Toluca Valley
}

\author{
Elizabeth Teresita Romero-Guzmán ${ }^{1 *}$, Lázaro Raymundo Reyes-Gutiérrez ${ }^{2}$, Liliana Romero- \\ Guzmán ${ }^{3}$, Héctor Hernández-Mendoza ${ }^{4}$, Lucía Clara Uría-Gómez ${ }^{5}$, Joel Gutiérrez-Reyes ${ }^{1,6}$ \\ ${ }^{1}$ Instituto Nacional de Investigaciones Nucleares, Departamento de Química, Gerencia de Ciencias Básicas; \\ Carretera México-Toluca, S/N. La Marquesa Ocoyoacác, Estado de México, MEXICO. ZIP 52750. \\ ${ }^{2}$ Universidad Autónoma Metropolitana, Unidad Lerma. Av. de las Garzas 10, Col. El Panteón, Lerma de \\ Villada, Municipio de Lerma, Estado de México, México. ZIP. 52005. \\ ${ }^{3}$ Universidad Autónoma del Estado de México, Facultad de Arquitectura y Diseño, Ciudad Universitaria, \\ Toluca de Lerdo, Estado de México, México, ZIP. 50110, México. \\ ${ }^{4}$ aInstituto de Investigación de Zonas Desérticas, UASLP, Altair 200, Z.P. 78377 San Luis, S.L.P., Mexico; \\ bUniversidad del Centro de México, Capitán Caldera 75, ZIP. 78250 San Luis, S.L.P., Mexico. \\ ${ }^{5}$ Red Automática de Monitoreo Atmosférico de la Zona Metropolitana del Valle de Toluca. Ex Rancho San \\ Lorenzo, Conjunto SEDAGRO, Edificio "C", planta baja S/N, San Lorenzo Coacalco Metepec, Estado de \\ México. \\ ${ }^{6}$ Instituto Tecnológico de Toluca. Av. Tecnológico S/N. Colonia Agrícola Bellavista, Metepec, Edo. De \\ México, México ZIP. 52149.
}

*Corresponding author: Elizabeth Teresita Romero-Guzmán, email: elizabeth.romero@inin.gob.mx; phone: +52 55 53297200, ext. 12279, Fax: +52 5553297301 .

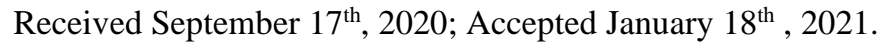

\section{DOI: http://dx.doi.org/10.29356/jmcs.v65i2.1445}

\begin{abstract}
Particulate matter (PM) is recognized as a type of pollutant emitted through the air that generates adverse health effects. Bioaerosols are PM of biological origin, that has not been morphologically characterized as exhaustively as other types of PM. The term bioaerosols collectively refers to all dead or living airborne particles with biological origins, including pollen, fungi, bacteria, viruses, plant or animal debris, as well as fragments and products of pathogenic microorganisms. Pathogenic airborne microorganisms may have public health consequences. Bioaerosols suspended in ambient air from the Metropolitan Zone of Toluca Valley (MZTV), State of Mexico were identified by scanning electron microscopy followed by energy dispersive xray spectroscopy, to determine their morphology, elemental chemical composition, and average sizes. The bioaerosols detected were pollen, spores, microorganisms, fragments, and diatoms that exhibited diverse morphological structures; while some particles had rough or smooth surfaces, others were spongy and spherical or had irregular or thorny surfaces. Others, yet, had well-structured surfaces such as the amoeba that were detected in the study. EDS analyses carried out on SEM samples demonstrated that $\mathrm{C}$ and $\mathrm{O}$ were the main chemical elements of them. The main components of diatoms were the silicon and oxygen. The particle radii (r) of detected pollen was $2 \mu \mathrm{m} \leq \mathrm{r} \leq 23 \mu \mathrm{m}$, spores were $0.17 \mu \mathrm{m} \leq \mathrm{r} \leq 3.7 \mu \mathrm{m}$, microorganisms were $0.16 \mu \mathrm{m}$ $\leq \mathrm{r} \leq 12 \mu \mathrm{m}$, and diatoms were $2.3 \mu \mathrm{m} \leq \mathrm{r} \leq 23 \mu \mathrm{m}$. Bioaerosols aerodynamic sizes range can be potentially poses adverse health effects.
\end{abstract}

Keywords: Bioaerosols; pollen; spores; microorganisms; diatoms; air contamination.

Resumen. El material particulado (MP) se reconoce como un tipo de contaminante emitido a través del aire que genera efectos adversos para la salud. Los bioaerosoles son MP de origen biológico, que no han sido 
caracterizados morfológicamente tan exhaustivamente como otros tipos de MP. El término bioaerosoles se refiere colectivamente a todas las partículas muertas o vivas transportadas por el aire con orígenes biológicos, que incluyen polen, hongos, bacterias, virus, restos de plantas o animales, así como fragmentos y productos de microorganismos patógenos. Los microorganismos patógenos transportados por el aire pueden tener consecuencias para la salud pública. Los bioaerosoles suspendidos en el aire de la Zona Metropolitana del Valle de Toluca (MZTV), Estado de México, fueron identificados mediante microscopía electrónica de barrido seguido de espectroscopía de rayos $\mathrm{X}$ de energía dispersiva, para determinar su morfología, composición química elemental y tamaño promedio. Los bioaerosoles detectados fueron polen, esporas, microorganismos, fragmentos y diatomeas que exhibieron diversas estructuras morfológicas; mientras que algunas partículas tenían superficies rugosas o lisas, otras eran esponjosas y esféricas o tenían superficies irregulares o espinosas. Otros, sin embargo, tenían superficies bien estructuradas como la ameba que se detectó en el estudio. Los análisis de MEB-EDS realizados en muestras demostraron que el $\mathrm{C}$ y el $\mathrm{O}$ eran los principales elementos químicos de las mismas. Los principales componentes de las diatomeas fueron el silicio y el oxígeno. El radio de partícula (r) del polen fue de $2 \mu \mathrm{m} \leq \mathrm{r} \leq 23 \mu \mathrm{m}$, las esporas fueron de $0.17 \mu \mathrm{m} \leq \mathrm{r} \leq 3.7 \mu \mathrm{m}$, los microorganismos fueron de $0.16 \mu \mathrm{m} \leq \mathrm{r} \leq 12 \mu \mathrm{m}$ y las diatomeas fueron de $2.3 \mu \mathrm{m} \leq \mathrm{r} \leq 23 \mu \mathrm{m}$. El intervalo de tamaños aerodinámicos de los bioaerosoles puede presentar efectos adversos para la salud.

Palabras clave: Bioaerosoles; polen; esporas; microorganismos; diatomeas; contaminación del aire.

\section{Introduction}

Aerosols have been growing in importance at international, national, and local levels due to their roles in environmental processes and aerosol technology. There has also been increasing interest in the physicochemical characterization of bioaerosols since they can easily penetrate and be deposited into the human body through the respiratory tract, potentially causing infections, allergic reactions [1], acute toxic effects, asthma, inflammatory lung diseases, or cancer [2,3]. Bioaerosols suspended in the air propagate quickly and easily in the common framework of humans [4].

Bioaerosol is a term used to describe dead or living airborne particles that have biological origins, including pollen, fungi, bacteria, viruses, plant or animal debris, and fragments and products of microorganisms [5-7]. They are transmitted through the air with particle sizes ranging from $0.001 \mathrm{~nm}$ to $100 \mu \mathrm{m}[7,8]$. Because of the micro to nano scale size, bioaerosols can probably be deposited in various parts of the body via the lungs and circulatory system [8].

Primary biological aerosol particles (PBAPs) is a term used to describe airborne solid particles (dead or alive) that originate from living organisms, including microorganisms and fragments of all varieties from living organisms. PBAPs includes viruses $(0.005 \mu \mathrm{m}<\mathrm{r}<0.25 \mu \mathrm{m} ; \mathrm{r}$ refers to particle radius), bacteria $(\mathrm{r} \geq 0.2$ $\mu \mathrm{m}$ ), algae, lichen moss spores, fern spores, fungal spores $(\mathrm{r} \geq 0.5 \mu \mathrm{m})$, pollen $(\mathrm{r} \geq 5 \mu \mathrm{m})$, plant debris (e.g., leaf litter), parts of insects, and human and animal epithelial cells (usually $r>1 \mu \mathrm{m}$ ) [1]. However, most biological aerosols arise from plants, but secondary sources include industry (textile mills), agriculture (fertilizing), and sewage plants.

The composition of PBAPs change throughout the year; PBAPs in the spring are typically composed of microorganisms, pollen, some spores, a few fragments, PBAPs in the summer are composed of microorganisms, pollen, spores, a few fragments, PBAPs in the autumn usually consist of microorganisms, fragments, spores, a few pollen, and PBAPs in the winter consist of microorganisms, fragments, spores, and some pollen [9]. The shapes of biological aerosols can be very diverse and range from spherical particles to needle like shapes and flakes.

In a preliminary study examining aerosols present in the Metropolitan Zone of Toluca Valley (MZTV), aerosols of biologic origin were detected [8-10]. These findings indicated the need for additional studies to elucidate the morphological characteristics and elemental chemical composition of bioaerosols throughout the Toluca Valley using scanning electron microscopy (SEM).

Due to increasing air pollution of the MZTV, both particles of inorganic and organic origin and particles of biological origin have been detected. However, identification of the bioaerosols was too basic to 
fully evaluate any adverse effects they could cause in exposed populations [11]. Bioaerosols can have adverse effects on humans, animals and plants. Many fungal spores have been found to contain compounds that can induce allergic reactions [7].

The purpose of this study was to identify the morphology, size, and elemental chemical composition of bioaerosols in six environmental monitoring stations in the MZTV using scanning electron microscopy.

\section{Experimental}

\section{Site sampling}

The MZVT has a network of air quality monitoring stations known locally as the Red Automática de Monitoreo Atmósferico de la MZTV (RAMA) that includes six stations: San Mateo Oxtotitlán, Metepec, San Lorenzo Tepaltitlán, San Mateo Atenco, Airport and San Cristóbal Huichochitlán. Some of the locations were relocated in 2010, including San Lorenzo Tepaltitlán and Toluca's downtown. The location of seven stations belonging to the air quality monitoring network of Toluca Valley was reported by Romero et al., 2012 and 2018 $[12,13]$. These monitoring stations have been classified into zones: Center (San Mateo Oxtotitlán), North (San Lorenzo Tepaltitlán, San Cristóbal Huichochitlán and Airport) and South (Metepec and San Mateo Atenco), Fig. 1.

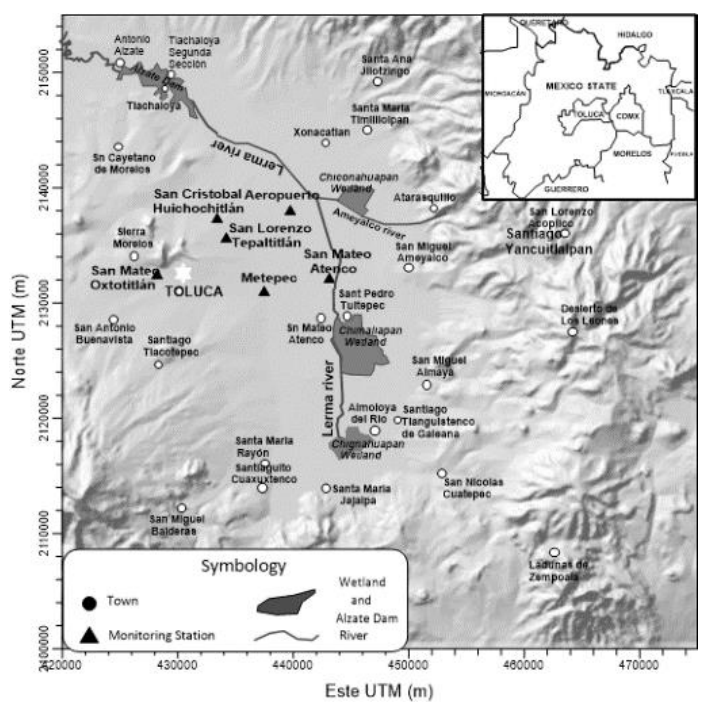

Fig. 1. Localization of monitoring stations in the MZTV.

\section{Sample monitoring}

Pluviometers (All Weather Rain Gauge) were installed to sampling pluvial water to collected bioaerosols through it at six stations of the Automatic Network of Atmospheric Monitoring (ANAM): San Mateo Oxtotitlán station, SMO; Metepec station, MET; San Lorenzo Tepaltitlán station, SLT; San Mateo Atenco station, SMA; Airport station, AER; and San Cristóbal Huichochitlán station, SCH. Rainfall was recorded May-September in 2015, and to capture greater volumes of water, $20 \mathrm{~L}$ containers were installed. Most of the results represent sampling during dry and warm days. A total of 110 rainwater samples (n) were collected during this period (SMO $n=18$, MET $n=18$, SLT $n=18$, SMA $n=20$, AER $n=18$ and $\mathrm{SCH} n=18$; replicates for each sample $=3)$. The average volume $(\bar{X})$ of collected water for each case was SMO $\bar{X}=37.34 \mathrm{Lm}^{-2}$, MET $\left(\bar{X}=35.85 \mathrm{Lm}^{-2}\right.$, SLT $\bar{X}=34.94 \mathrm{Lm}^{-2}$, SMA $\bar{X}=37.51 \mathrm{Lm}^{-2}$, AER $\bar{X}=37.81 \mathrm{Lm}^{-2}$ and SCH $\bar{X}=36.29 \mathrm{Lm}^{-2}$; Samples were preserved at $4^{\circ} \mathrm{C}$ and brought to the laboratory. Each sample of $300 \mathrm{~mL}$ was filtered using $47 \mathrm{~mm}$ diameter Whatman nitrocellulose membrane filters with pore sizes of $0.45 \mu \mathrm{m}$ using a vacuum filtration system (pressure 
and vacuum pump (4 $\mathrm{Kg} \mathrm{cm}^{-3}$ ) welch brand and a funnel filtering apparatus wheaton brand). This method separated particulate material from water in each sample.

\section{SEM analysis}

$10 \mathrm{~mm} \times 10 \mathrm{~mm}$ pieces of filters containing deposited particles and blank filters (with no particles) were mounted onto a $20 \mathrm{~mm}$ diameter SEM aluminium stub with copper tape prior to gold coating (Denton Vacuum Desk II Sputter Coater). The coated filters were examined with a high-resolution SEM (JEOL 5900$\mathrm{LV} ; 20 \mathrm{kV}$ beam size). Morphological and structural characterization was done using a systematic sampling method. Initially, the microscope was focused to obtain general overviews, but was then focused on the upper left edge and right edge, lower right, and left edge, far right, left, and finally at the center at a magnification of $1,000 \mathrm{X}$. The magnification was increased to $25,000 \mathrm{X}$ when particles of interest $(0.5-100 \mu \mathrm{m})$ were found. The magnification was adjusted to ensure that the visual properties of the particles were sufficiently clear and to analyze and record their number, size and shape. During SEM analysis, some of the detected particles were identified as bioaerosols based on previously published SEM images [12] of fungi, bacteria, house dust mites, pollen and microphytes [13]. EDS analyses (OXFORD Link Pentafet X-ray analyzer) were carried out on the focused particles to corroborate their organic or inorganic nature. The SEM-EDS analysis was highly representative with more than 2000 particles analyzed and homogeneous in the samples, but selective in the bioaerosols. The precision of a quantitative analysis is greater than $\pm 2 \%$ and the detection limits are around $100 \mathrm{ppm}$ in routine analysis, reaching $10 \mathrm{ppm}$ in exceptional circumstances.

\section{Results and discussion}

Bioaerosols in ambient air have significant societal impacts ranging from climate change to affecting public health [14]. About 30\% of the total mass of particles corresponds to biological material [9]. In this study, bioaerosols composition changed throughout the time, in this case from May to September. Samples collected in the summer consisted of microorganisms, pollen, spores, and a few fragments, and samples collected in the autumn contained microorganisms, fragments, spores, some pollen, and diatoms.

Analysis conducted by SEM determined there were particles from different natural sources. The elemental chemical composition of some bioaerosols was based on carbon and oxygen, while the elemental chemical composition of the diatoms were silicon and oxygen. The particle forms varied from having rough surfaces to having spongy and spherical shapes or being formed by smooth and irregular materials. Figs. 2 to 8 shows the variety of bioaerosols that were found in samples from the different monitoring stations of the MZTV.

\section{Pollen}

The pollen detected in this study exhibited many shapes and sizes. In much of the long history of plant life on land, plants had to be located very close to each other, almost touching, to breed. Since then, plants have evolved to produce thousands to billions of individual pollen grains so that at least one grain can lead to breeding success. To improve the spread of pollen grains, the pollen bags of plants have evolved to explode [15].

The destination of each of those billions of pollen grains is the naked ovule (the future seed) of another plant of the same species. While air can visually appear to be clear to the naked eye, it is actually full of unsuccessful pollen grains floating in the wind. As such, billions of grains reach the stratosphere at any one time [16]. Pollen eventually falls and accumulates in sediment, layer upon layer, especially in the bottom of lakes and ponds [17].

The main apertures of the detected airborne pollen consisted of the following types: monoporate, biporate, triporate, periporate, periporate, high spine compositae and vesiculate. Similar to the current results, Chang et al., 2018 [18] also detected pollen grains with periporate apertures. In addition, pollen grains with high spine compositae and vesiculate have also been reported by Prabhakar et al., 2017 and Nakagawa et al., $2000[19,20]$. The pollen visually exhibited smooth, rough, or thorny surfaces or signs of boring, which was the most representative trait of these materials. Pollen grain size varied from 4 to $45 \mu \mathrm{m}$. The chemical composition of the sampled pollen was mainly carbon and oxygen. 
Based on its source, the periporated pollen likely came from the quelite cenizo Chenopodium berlandieri Moq. The vesicular pollen likely originated from Pinus sp. [19,20]; the pollen of these trees, which float in the air with support from its two air vesicles, can aggravate symptoms in people with allergies since the pollen grains are able to reach high concentrations, Fig. 2.
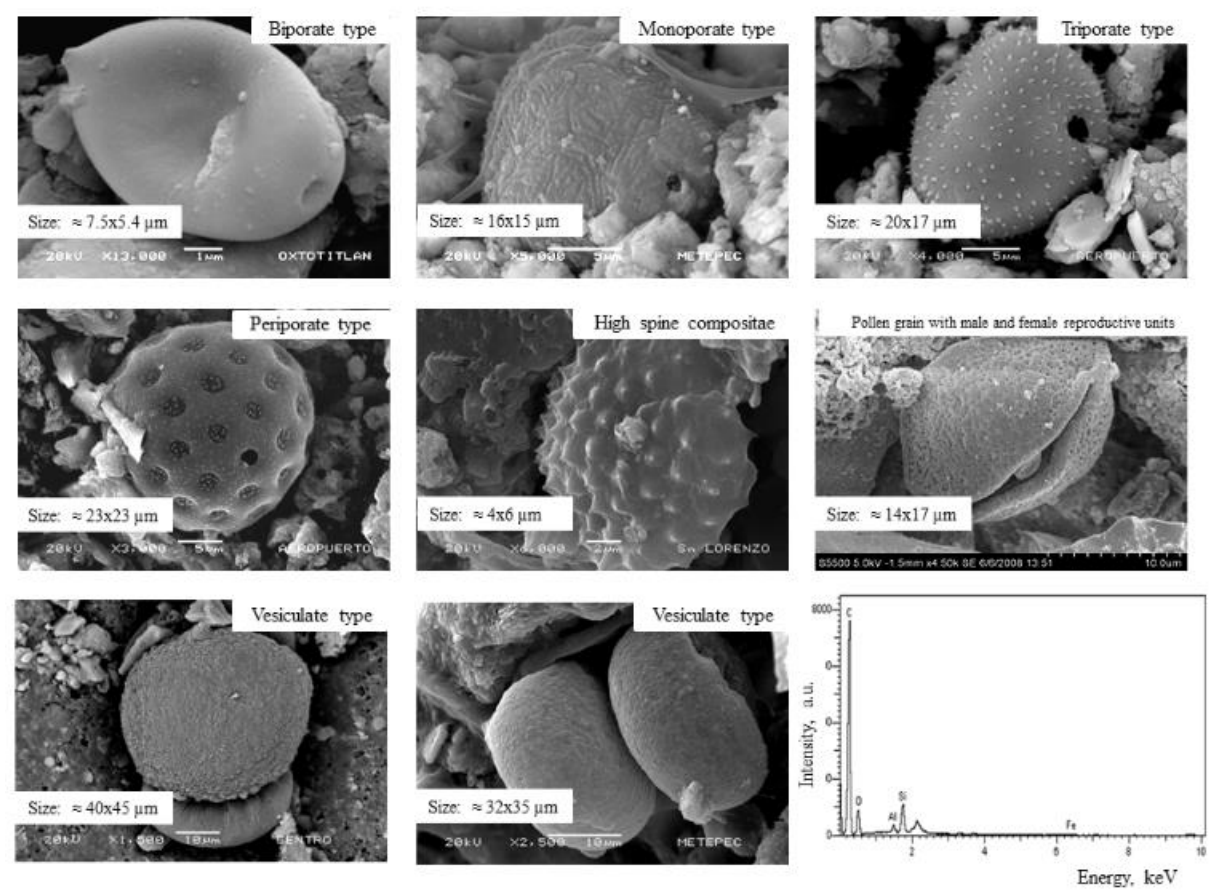

Fig. 2. SEM micrographs of a pollen grain variety identified in MZTV.

Fig. 3 shows periporate pollen analyzed from quelite cenizo. Their size was approximately $20 \mu \mathrm{m}$ and their chemical composition was based on carbon and oxygen.

These results confirm the presence of this pollen type in the air of the MZTV.

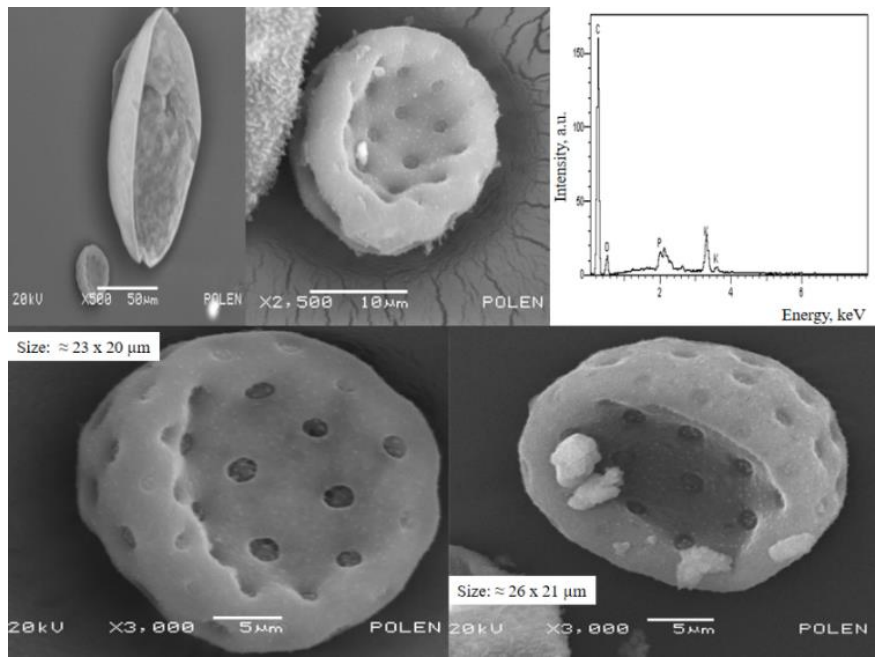

Fig. 3. Periporate pollen grains from quelite cenizo analyzed by SEM 
Fig. 4 presents pollen with cross-linked structures, compositions based on carbon and oxygen, sizes ranging between $8 \mu \mathrm{m}-36 \mu \mathrm{m}$. In general, the pollen particles were composed $59.26 \%$ of carbon and $37.41 \%$ of oxygen.
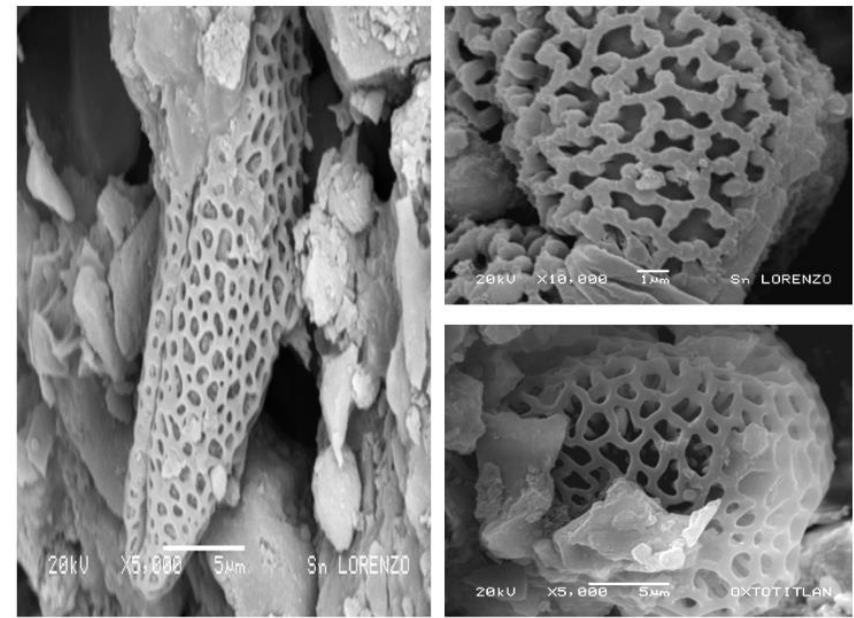

Fig. 4. Cross-linked structure of pollen observed by SEM.

\section{Spores}

In Fig. 5, spores are shown in all micrographs (a-h) with magnifications from 2,500 X to 20,000 X. These micrographs demonstrate the presence of released spores on the walls of pollen grains. The spore sizes were small, mainly 0.35 to $7.5 \mu \mathrm{m}$. They were chemically composed of carbon and oxygen as shown in the EDS spectrum.
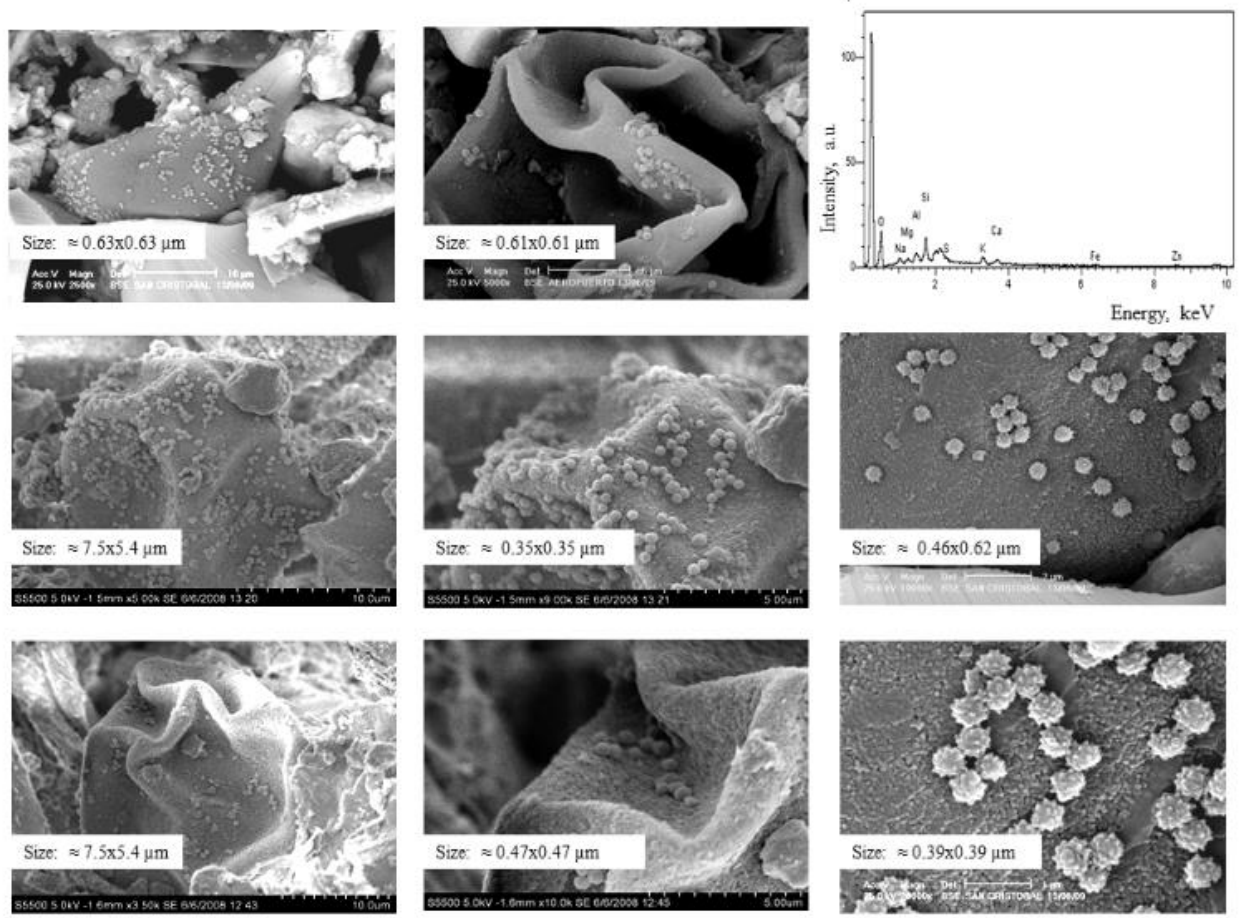

Fig. 5. Spores found in the Metropolitan Zone of the Toluca Valley. 
Spores are asexual reproductive cells that produce new organisms when they divide by mitosis without fusion with other cells. Spores are an important stage life cycle stage for many plants, fungi and algae [21,22].

\section{Microorganisms}

Microorganisms such as amoeba and fungi were detected in throughout the collected samples, Fig. 6. Fig. 6(a) shows a micrograph of a testate amoeba's shell. If the amoeba were alive, it would protrude from the open end. The size of shell is of approximately 21.8 to $25.39 \mu \mathrm{m}$. Fungus was observed with sizes of 0.60 to $0.70 \mu \mathrm{m}$ and carbon and oxygen based compositions, Fig. 6(b).

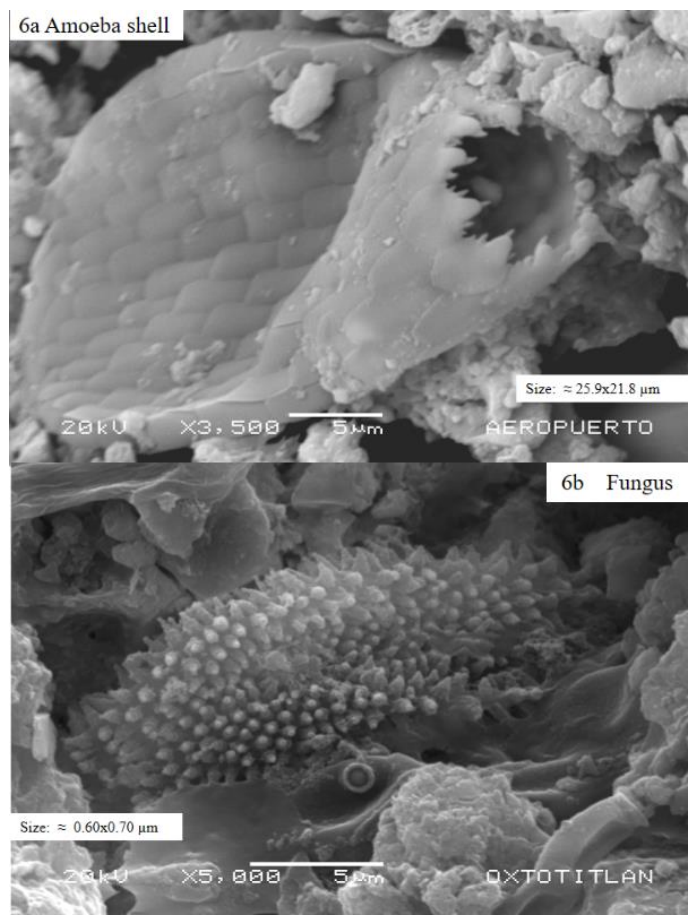

Fig. 6. Microorganisms, including amoeba and fungi that were present in the atmosphere.

Microorganism are living organisms that can only be seen through a microscope, hence its name. Most microorganisms are unicellular although some may be multicellular. Microorganisms include bacteria, protozoa and fungi. Viruses are considered by some to be living because they carry genetic material $[2,3]$. Previous studies have revealed surprisingly high concentrations of these bioaerosols particles in ambient air during the summer season $[3,7]$.

\section{Fragments}

Pollen with reticulate ornamentation or regulate diverse ornamentation was detected in the current study, similar to the particles reported by Mondragón 2006 [23], Fig. 7.

Fig. 7(a) shows fragments of material with eruptions on their surfaces. The rashes have smooth appearances; in the case of Fig. 7(b), a smooth-looking material can be seen with some hexagonal type marks. Fig. 7(c) shows a material with spines, which were apparently homogeneously distributed. Lastly, Fig. 7(d) presents a material which had well-distributed homogeneous holes that emerged from its surface. It had a semismooth appearance, but it presented areas with wrinkles on its surface.

The small spherical objects seen in Figs. 7(e,f) are known as brochosomes, these are dead materials produced by leafhoppers as wastes; their sizes ranged from $0.33 \mu \mathrm{m}$ to $0.70 \mu \mathrm{m}$. The brochosomes resemble an 
open-face football with rods along the seams reported by Wittmaack et al., 2005 and Wittmaack in 2005 too $[7,24]$.
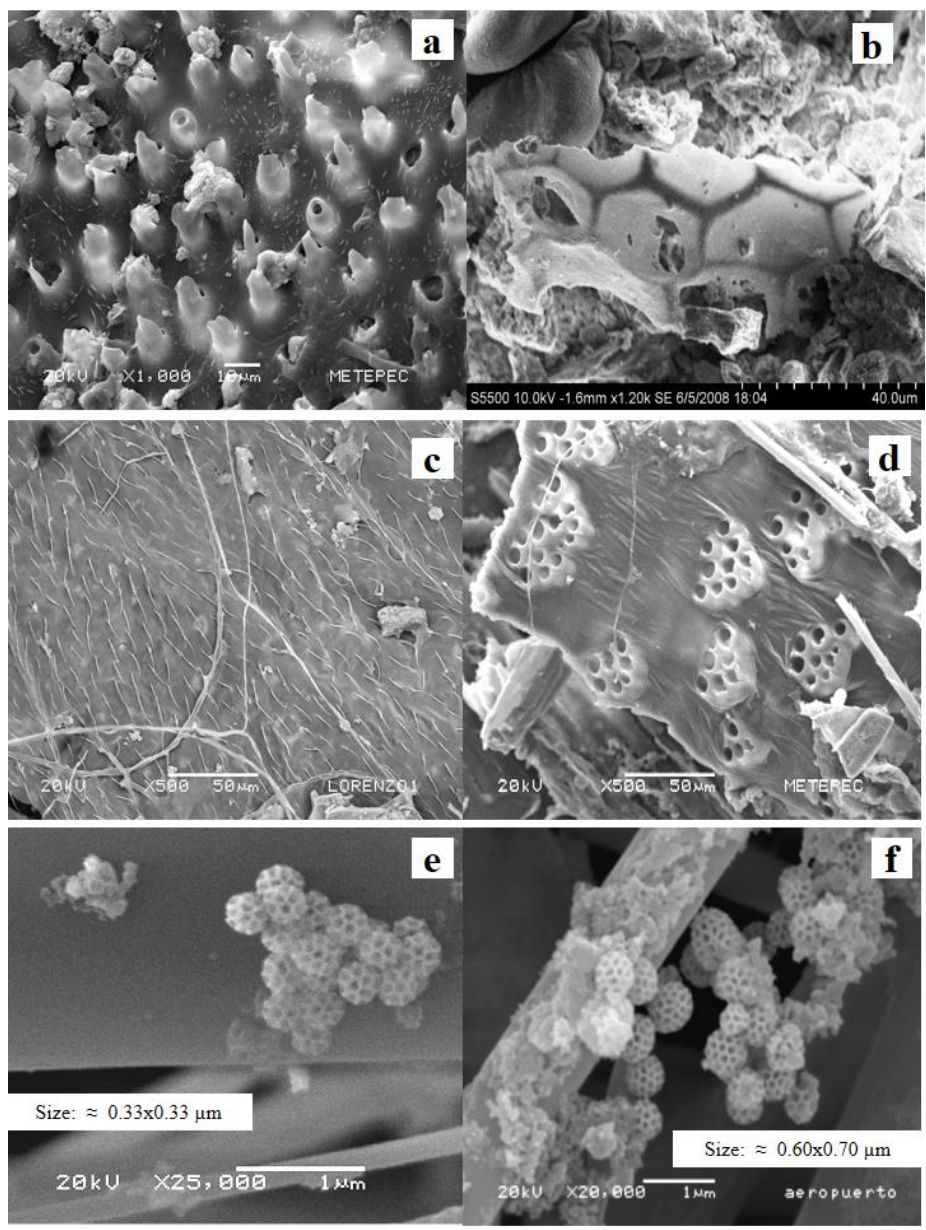

Fig. 7. Airborne biomaterial fragments including brochosomes from wastes of leafhoppers identified by SEM.

\section{Diatoms}

We found a high presence of diatoms throughout air samples. As shown in Fig. 8, a high diversity of diatoms were found in the air from the MZTV. The diatoms had frustules, which are shells that protect the cells from unicellular algae, with a high content of hydrated $\mathrm{SiO}_{2}$.

Diatoms are unique forms of algae that grow silica shells that are preserved in lacustrine sediments after they die. Among the phytoplankton, diatom algae are the dominant community in the aquatic ecosystem and contribute significantly towards removing heavy metals from polluted areas. This makes them valuable assets for restoring polluted environments to their previous conditions [25]. Microalgae have the ability to generate highly ornamented, fanciful and elegant porous silica cell walls [26]. Diatom frustules [27-29] are different for each species, so they can be identified through a microscope.

Two unequal halves that fit onto one another form the frustule or teak (epiteca = external part; hypotheca: part embedded inside). Frustules exhibit a variety of forms, some of which are very beautiful and ornate, that generally consist of two asymmetric parts or valves with a division between them, hence the name of the group [30]. 
As shown in Fig. 8(a), the current study detected a diatom frustule with eucentric circular symmetry and characteristic spines surrounding the valve. This valve surface ornamentation was radially symmetric around a central point and the valve outline was circular. Its size was $\approx 18.8$ to $15.7 \mu \mathrm{m}$. The diatom had porosity, circular shape, and a pore size from 0.14 to $0.29 \mu \mathrm{m}$. As displayed in Fig. 8(b), there was detection of a diatom with porosity and a rectangular shape and a size of $\approx 45.3$ to $9.3 \mu \mathrm{m}$.

Fig. $8(\mathbf{c})$ displays a rectangular diatom that was $\approx 17$ to $20 \mu \mathrm{m}$ in size, and it had porosity with a small pore size. As shown in Fig. $8(\mathbf{d})$, a rectangular shaped diatom with a $\approx 11$ to $25.7 \mu \mathrm{m}$ size and porosity with a pore size of $\approx 0.33 \mu \mathrm{m}$ was detected. This is similar to the findings of Nahar et al. 2018 [28]. As displayed in Fig. $8(\mathbf{e})$, an oval diatom with a size of $\approx 5$ to $11.67 \mu \mathrm{m}$ was observed. It exhibited porosity that was distributed between smooth surface areas. A porous diatom with a centric frustule, $\approx 10.22$ to $10.89 \mu \mathrm{m}$ size, and pore size of $\approx 0.22 \mu \mathrm{m}$ was also detected, Fig. 8(f). Finally, Figs. 8(g-h-i) show three diatoms primarily with oval shapes and sizes of $\approx 18.5$ to $34.5 \mu \mathrm{m}, \approx 5.43$ to $12.57 \mu \mathrm{m}$ and $\approx 4.73$ to $9.64 \mu \mathrm{m}$, respectively. Foets et al., 2020 [30], also reported the diatom shown in Fig. 8(h). The diatoms, in this study, were mainly composed of silicon and oxygen as observed in the EDS spectrum in Fig. 8(j) and Lu et al., reported in 2015 [31]. Interestingly, the arrangement of diatom pores, in fact, provides a very specific coordinate system that has adapted to the shape, as reported by De Tommasi et al., 2017 [26].

The presence of diatoms in the samples is likely due to the fact that bodies of water were located close to the areas of study and that diatoms are used in many of the industrial zones in the MZTV. Overall, the frustules of the diatoms observed in this study were variable in ornamentation and type with sizes widely ranges from 8 to $20 \mu \mathrm{m}$.
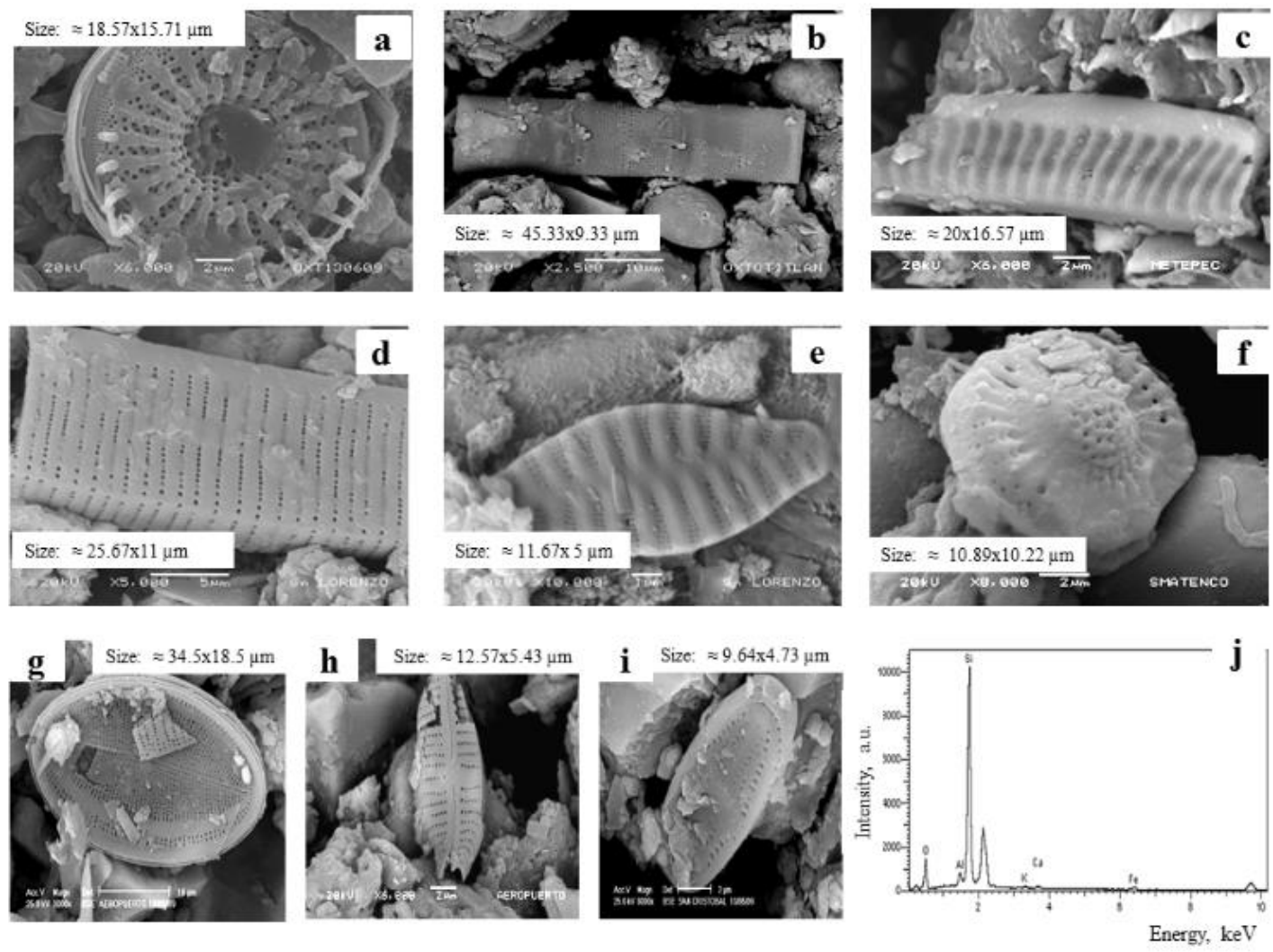

Fig. 8. Diversity of diatoms found in the air from MZTV. 


\section{Conclusion}

Airborne bioaerosols present in the MZTV were composed of pollen, spores, microorganisms, fragments and diatoms, which collected through wet monitoring.

The bioaerosols detected in this study exhibited diverse morphological structures; while some particles had rough or smooth surfaces, others were spongy and spherical or had irregular or thorny surfaces. Others, yet, had well-structured surfaces such as the amoebas that were detected in the study. The presence and type of aerosols detected in this study also varied based on the time of year. EDS analyses carried out on SEM samples demonstrated that carbon and oxygen were the main chemical elements of pollen, spores, microorganisms and fragments. The main components of diatoms were the silicon and oxygen.

The particle radii (r) of detected pollen was $2 \mu \mathrm{m} \leq \mathrm{r} \leq 23 \mu \mathrm{m}$, spores were $0.17 \mu \mathrm{m} \leq \mathrm{r} \leq 3.7 \mu \mathrm{m}$, microorganisms were $0.16 \mu \mathrm{m} \leq \mathrm{r} \leq 12 \mu \mathrm{m}$, and diatoms were $2.3 \mu \mathrm{m} \leq \mathrm{r} \leq 23 \mu \mathrm{m}$. It should be noted that the bioaerosols aerodynamic sizes were $0.3 \mu \mathrm{m}$ to $45 \mu \mathrm{m}$, a size range that potentially poses adverse health effects.

The presence of biological particles in the air in the Metropolitan Zone of the Toluca Valley may cause harm the health of the population during chronic exposure in short or long term. Exposure to air pollution is a significant environmental risk for many diseases, including respiratory infections, lung cancer, chronic respiratory and cardiovascular diseases. The current ambient Air Quality Mexican Official Standards at the federal level defined by the Secretary of Health, which regulate seven criteria pollutants by setting maximum allowable concentrations. The Secretary of Health issued a series of Mexican official standards, or normas oficiales (NOMs), that regulate maximum concentrations of environmental contaminants, included the particulate matter $\left(\mathrm{PM}_{2.5}\right.$ and $\left.\mathrm{PM}_{10}\right)$ NOM-025-SSA1-2014, particles smaller than 10 microns $\mathrm{PM}_{10}$ (24 hour limit: $50 \mu \mathrm{g} \mathrm{m}^{-3}$, as an average of 24 hours. Annual limit: $35 \mu \mathrm{g} \mathrm{m}^{-3}$, as an annual average), and particles smaller than 2.5 microns $\mathrm{PM}_{2.5}$ (24 hour limit: $30 \mu \mathrm{g} \mathrm{m}^{-3}$, as an average of 24 hours. Annual limit: $10 \mu \mathrm{g} \mathrm{m}^{-3}$, as an annual average).

\section{Acknowledgements}

We are grateful to the COMECYT EDOMEX-CO-01-09 for financial support. The authors want to thank to Dr. Miguel José Yacamán at UTSA Physics \& Astronomy and ANAM personnel, Q. Carlos Edgardo Aguirre Campuzano. We want to thank to Jorge Prado Pérez for their technical help.

\section{References}

1. Pillai, S. D. Water Res. 2007, 79, 270-278.

2. Qi, D.; Guan, J.; Wu, E. Radiol. Infec. Dis. 2018, 5, 143-147.

3. Li, W.; Liu, L.; Xu, L.; Zhang, J.; Yuan, Q.; Ding, X.; Hu, W.; Fu, P.; Zhang, D. Sci. Total Environ. 2020, 719, 137520.

4. O`Connor, D. J.; Daly, S. M.; Sodeau, J. R. Waste Manag. 2015, 42, 23-30.

5. Yao, M. J. Aerosol Sci. 2018, 119, 91-96.

6. Nasir, Z. A.; Colbeck. I.; Sultan, S.; Ahmed, S. Environ. Pollut. 2012, 168, 15-22.

7. Wittmaack, K. Atmos. Environ. 2005, 39, 1173-1180.

8. Humbal, C.; Gautam, S.; Trivedi, U. Environmental International 2018, 118, 189-193.

9. Colbeck, I. Physical and chemical properties of atmospheric aerosols. Environmental Chemistry of Aerosols. Nueva Delhi:Blackwell Publishing. U.K. 2008, 255.

10. Gutiérrez-Reyes, J.; Romero-Guzmán, E. T.; Reyes-Gutiérrez, L. R.; Sandoval-Pérez, A.; AguirreCampuzano, C. E. El ININ hoy, 2009, 16-22. 
11. González-Lozano, M. C.; Cerezo-Moreno, A.; González-Macías, M. C.; Salazar-Coria, L. J. Mex. Chem. Soc. 1999, 43, 155-164.

12. Romero-Guzmán, E. T.; Reyes-Gutiérrez, L. R.; Sandoval-Pérez, A. Chemical and Ecology 2012, 28, 574-588.

13. Romero-Guzmán, E. T.; Hernández-Mendoza, H.; Kuri-Cruz, A.; Reyes-Gutiérrez, L. R. Chem. Eco. 2018, 34, 482-494.

14. García-Alcega, S.; Ahmad, N.Z.; Cipullo, S.; Ferguson, R.; Yan, C.; Whitby, C.; Dumbrell, A. J.; Drew, G.; Colbeck, I.; Tyrrel, S.; Coulona, F. Sci. Total Environ. 2020, 719, 137542.

15. Rizzardo, R. A. G.; Milfont, M. O.; Da Silva, E. M. S.; Freitas, B. M. Anais da Academia Brasileira de Ciências, 2012, 84, 1137-1145.

16. Dunn, R. National Geographic. 2019 https://www.nationalgeographic.com/magazine/2009/12/pollen/

17. Colinvaux, P.; Moreno Patiño, J. E. Overseas Publishers Association, 2005, 65-75.

18. Chang, H.; Guo, J.; Fu, X.; Liu, Y.; Wyckhuys, K. A. G.; Hou, Y.; Wu, K. Int. J. Mol. Sci. 2018, 19, 567-582.

19. Prabhakar, A. K.; Lai, H. Y.; Potroz, M. G.; Corliss, M. K.; Park, J. H.; Mundargi, R. C.; Cho, D.; Bang, S.; Cho, N.J. J. Ind. Eng. Chem. 2017, 53, 375-385.

20. Nakagawa, T.; Edouard, J. L.; De Beaulieu, J. L. Review of Palaeo botany and Palynology, 2000, 108, $1-15$.

21. Brown, R. C.; Lemmon, B. E. New Phytol. 2011, 190, 875-881.

22. Kim, P. E.; Musher, D. M.; Glezen, W. P.; Rodríguez-Barradas, M. C.; Nahm, W. K.; Wright, C. E. Clinical Infectious Diseases, 1996, 22, 100-106.

23. Mondragón, A. Bioagro, 2006, 18, 139-143.

24. Wittmaack, K.; Wehnes, H.; Heinzmann, U.; Agerer, R. Sci. Total Environ. 2005, 346, 244-255.

25. Kiran, M.T.; Saxena, A.; Tiwari, A. Bioresource Technol. 2020; doi: https://doi.org/10.1016/j.biortech.2020.123068.

26. De Stefano, M.; De Stefano, L.; Congestri, R. Superlattices Microstruc. 2009, 46, 64-68.

27. De Tommasi, E.; Gielis, J.; Rogato, A. Mar. Genomics 2017, 35, 1-18.

28. Nahar, S.; Tanti, B. J. Mater. Sci. 2018, e-ISSN: 2321-6212, p-ISSN: 2347-2278.

29. Leone, G.; Vona, D.; De Giglio, E.; Bonifacio, M. A.; Cometa, S.; Fiore, S.; Palumbo, F.; Ragni, R.; Farinola, G.M.; Cicco, S.R. Data in Brief 2019, 24, 103831.

30. Foets, J.; Wetzel, C. E.; Teuling, A. J.; Pfister, L. PeerJ. 8: 2020, e8296 DOI 10.7717/peerj.8296.

31. Lu, J.; Sun, C.; Wang, Q.J. J. Bionic Eng. 2015, 12, 98-108. 